\title{
Information Search Behavior: Proposal of Study with Investors in the Stock Market
}

\author{
Elaine Cristina Lopes, Marta Lígia Pomim Valentim \\ Department of Information Science, Universidade Estadual Paulista Júlio de Mesquita Filho (UNESP), Marilia, Brazil \\ Email: lainelopes@hotmail.com
}

Received July 31, 2013; revised August 31, 2013; accepted September 6, 2013

Copyright (c) 2014 Elaine Cristina Lopes, Marta Lígia Pomim Valentim. This is an open access article distributed under the Creative Commons Attribution License, which permits unrestricted use, distribution, and reproduction in any medium, provided the original work is properly cited. In accordance of the Creative Commons Attribution License all Copyrights (C) 2014 are reserved for SCIRP and the owner of the intellectual property Elaine Cristina Lopes, Marta Lígia Pomim Valentim. All Copyright (C) 2014 are guarded by law and by SCIRP as a guardian.

\begin{abstract}
With the aim of analyzing the information search behavior of investors working in the stock market, this research sought to raise the aspects related to this behavior with focus on the cognitive and causal aspects which pervaded the need for information of these investors. For that, the general pattern of informational behavior proposed by Wilson [1] and the analysis of a report from an investor of the stock market area were used as the basis for the analysis and reflection. The report of only one investor was used as the basis for investigation, turning it impossible to extrapolate such result to a greater universe. The objective of this research was to investigate the need for information, the context and the intervenient variables which might interfere or not in the information search behavior of investors, in an attempt to get a deeper comprehension about the subject, as well as to propose the continuity of studies with basis on this study proposal.
\end{abstract}

\section{KEYWORDS}

Stock Market; Information Behavior; Information Search Behavior

\section{Introduction}

The information search behavior is an issue that has already been discussed for such a long time in the information science field and, in the general way, the studies accomplished in the scope aim to investigate how the individuals search information about a determined topic, considering the cognitive aspects, the sources used, as well as the need for information that moves these individuals.

In the field of stock market, the information is critical, considering it deals with an environment in which shares of companies are negotiated by means of purchase and sold by investors. In this context, the investors need relevant information which, once appropriated by them in an efficient way, subsidizes the construction of "new" knowledge and, therefore, fundamental to their analysis and later decision-making. However, at this complex scenario, in which changes are constant considering the macroeconomic and microeconomic factors, in some cases the investors are led to get from a state of information search on a regular basis, to a state of need derived of unusual situations, such as an economical crisis for instance.

With the aim of analyzing the information search behavior of investors working in the stock market, this research sought to raise the aspects related to this behavior with focus on the cognitive and causal aspects which pervaded the need for information of these investors. For that, the general pattern of informational behavior proposed by Wilson [1] and the analysis of a report from an investor of stock market area were used as the basis for the analysis and reflection.

By observing the non-existence of researches about information search behavior with focus on investors of the stock market area, this work aims to start the reflection about the importance of applying the elements in this context. Thus, it was opted for the analysis of only one case, whose aim was to identify gaps and possibilities for future research which may contribute to deepening the studies regarding this problem. 


\section{Information Search Behavior}

The studies on the existing relation between the need for information and the information search process have been developing and expanding its scope in the Information Science area. This is due to the conception that when a determined need for information occurs, the individual needs information as an input to supply the existing cognitive gaps, whose process takes it to the construction of "new" knowledge. This process happens through dynamics used by the individual on their own way, once that each individual defines an action strategy when recognizing his need for information, as well as defines his own strategy of using it.

On this perspective many approaches have been used to analyze the user behavior. Acordding to Nassif et al. [2] the studies about needs and use of information try to investigate how the individuals search information about something, what sources are important to them and how they use them, as well as how and for what purpose they search the information and how it will be applied.

It is pointed out that the information search behavior analysis gives support not only to know about the act itself developed by the individuals, but also to know the context which involves this behavior. In a general way, great part of the considerations related to the information search are more associated to how people use specific systems of information, than to the specific and private aspects of information search, such as the process itself of search and transference of information. (WILSON) [3].

Hence, regardless the context which involves a determined information search behavior, as well as the individuals taking part in this process, for each informational behavior there is a reality, an objective, an ability of interaction with the system, as well as the perception and the feelings of the informational individual. The distinct realities influence the informational individual, because the user of a library, a consumer, a client of a company or an investor needs information, and according to their needs these have distinct feelings, distinct perceptions and distinct views about the context, directly influencing the informational behavior and, consequently, the result of the search, appropriation and construction of "new" knowledge.

Considering all these aspects, the model of Kuhthau [4] stands out, presenting a systematization of feelings, thoughts and actions of the individuals during the present steps in the referred model, considering that the feelings are part of the information search process (Figure 1). The reactions which occur at the stage where the user still does not know what he needs informationally are also considered. In the referred model, several feelings are analyzed and they may be found in distinct information search behavior, such as confusion, anxiety, questioning and frustration, until the moment in which the individual gets satisfied with the obtained result or gives the search process up. For this author, each individual has a view of the world and, therefore, the search process is influenced by the individual background, as well as by the reality around him.

The people actively and constantly construct their view of the world assimilating and accommodating the new information with what they already know or to some experience already experimented beforehand. The information search is a process which involves the individual background and, therefore their feelings, thoughts and reflections, influencing directly in the following actions (KUHLTHAU) [4].

Ellis (1989 apud Wilson, 1999) [5] presents certain patterns of behavior which may occur in the information search process. The model proposed by this author (Figure 2) considers on his structure some characteristics of the search activity behavior, in a way that the interrelation or the interactions are detailed by means of characteristics which recurrently are observed during the information search process, carried out by distinct individuals. Ellis points out that the process will depend on the single circumstances present in the context which will influence decisively to the actions/activities which the individual will perform during the search.

The author defines the characteristics of Figure 2 as follows: Starting: it is about the means used by the individual to start the information search; Sequence: following the indications of already known materials or by

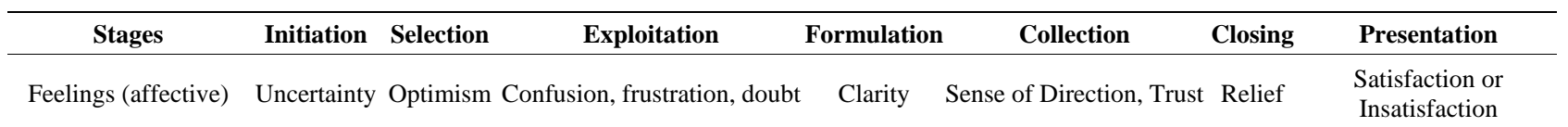

\begin{tabular}{lll} 
Thoughts (cognitive) $\quad$ Ambiguity & Interest Increase \\
Actions (physical) & Search of Relevant Information \\
\hline
\end{tabular}

Source: Kuhlthau [6].

Figure 1. Kuhlthau-Information search process. 


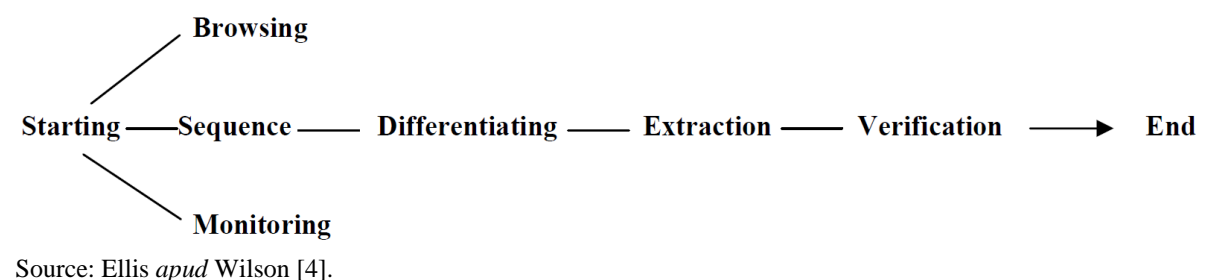

Figure 2. Ellis-Information search process.

means of citation indexes analysis; Browsing: semi-directed or semi-structured of search; Differentiating: evaluating the sources of information in a way to filter and reduce the quantity of obtained information; Monitoring: keeping up-to-date constantly; Extraction: identification and selection of relevant material in a determined information source; Verification: analysis of reliability of the obtained information; End: systematization of information obtained in a consistent way.

According to Wilson [7] the information search behavior consists in distinct actions applied to the information obtaining, as the consequence of the need to satisfy some objective. In the course of the search, the individual may interact with the manual information systems or with computerized information systems. On his model, Wilson [1] presents a macro view of the informational behavior, however, he puts the individual in the center of the model, highlighting the existing barriers and representing them by intervening variables, which are recognized after the identification of the informational need.

Aiming to bring together the several types of studies about the information search behavior, Wilson [5] proposed a conceptual model (Figure 3), based on an analysis of literature about different models proposed before.

According to Wilson (1999) informational behavior may be understood as the most general field of investigation which includes the subset information seeking behavior, more concerned about the variety of methods used by the individuals in the discovery and access to the information resources which, in turn, contemplates the subset seeking behavior in information systems which concerns about specific matters related to the interaction of the individual with information systems.

It is highlighted that the informational behavior usually comprehends one of the stages of development of a determined task/activity, congregating the need, search and use of information. In this sense, Information search behavior is related to the information analysis which will be used to the performing of a determined activity/task. Thus, it is understood that the information search behavior receives many contributions from the Information Science field, because the research may be directed to different public and contexts.

On this perspective, other areas may benefit themselves from the studies and research directed to the anal-

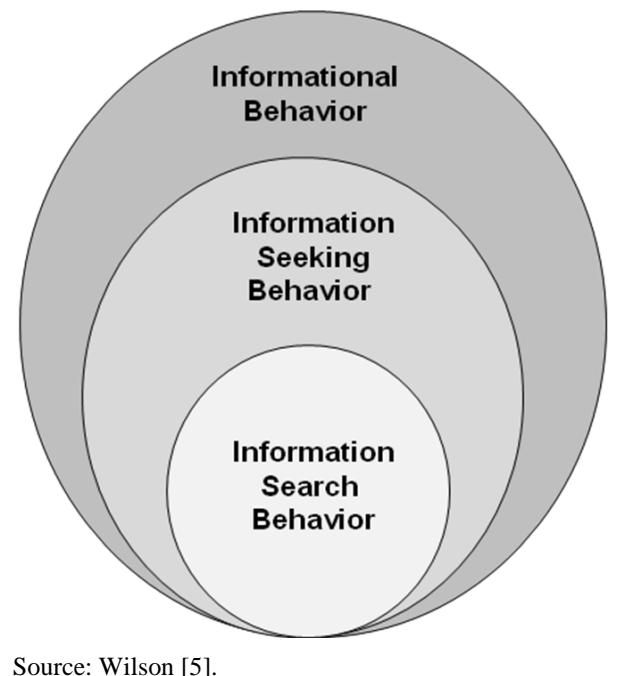

Figure 3. Wilson-Informational behavior.

ysis of the information search behavior. In this perspective, Wilson [3] points out that these studies are not limited to the application of library users and/or information and documentation centers, on the opposite they may be applied to a consumer who seeks information about a product, or an individual who suffers, for example, from Alzheimer and who seeks for more information.

\section{Need for Information within the Stock Market}

The stock market is a segment of the financial market where operations with securities issued by companies are carried out, and their main function is to provide an environment for the carrying out of business of purchase and sale of these securities, where the main ones are the shares, the debentures and the warrants. To Andrezo and Lima [8], the stock market is composed by the set of agents and financial instruments involved in operations with short-term, medium-term or random term securities.

First, in order to make it possible to deepen the selected topic it is important to characterize the role of the main agents involved in the process of operationalization of the stock market. When opening capital by selling part of its shares in the stock market, a company seeks to obtain resources which will suit to meaningful investments in their business. According to Pinheiro [9], the needs 
which may be satisfied with the opening of capital are usually connected to the financing of expansion projects such as the expansion of production lines, company modernization, the technological innovation, among other goals.

On the other hand, the investor applies their resources in shares of a determined company considering the expectation of future profit. Regardless the investor profile, what he expects is the company to make profit, so that, as consequence, his shares become valuable, and along with this his investments have positive income. In general, such expectations are based in the information these investors have around the business and the marketplace in which the company operates. Therefore, the transparency in the disclosure of the information transmitted is fundamental, especially about the financial situation of the company.

In this context, the information is undoubtedly a fundamental element to the stock market participants, as it is through the evaluation of an information set that these participants construct the essential knowledge to their investment decisions. However, as important as the format and support used to the spread of information, resides the service to the informational need to the decision making. Thus, the information may be considered as an input which provides "new" knowledge to the individuals, influencing in the decision making in relation to the investment that they want to make, therefore the way these investors search information should be considered as fundamental at this context.

When it is observed from the providing side or there are definitions, such as the structural one, which indicates the information to be the result of the static relation between material objects, regardless the action of the human beings, or there is the definition related only to the message, in which the information is indicated as a symbol produced by a provider to carry out a transference process. On these definitions, the information receptor is excluded of the process, or is not necessary to its explanation. The information definitions when related to the receptor reinforce the semantic intentions of the transference, featuring the concept with the meaning of the message, its effective use and the action resulting of the use (BARRETO) [10].

The consisting elements of efficiency in the relations among companies and investors are transparency, quality standards in the accounting disclosure and other criteria which ensure wide access of the investors to the relevant information, to the correct evaluation of the risk expectations and return of investments (PINHEIRO) [9].

The existing relations among the parts involved in this process have been object of study in the last years, since such relations should be guided by criteria of reliability and transparency, mainly regarding the information avail- able to the investors and they foster the construction of necessary knowledge to the decision making of the investment itself. However, the information search behavior about the companies by investors still does not have the search scope in the Brazilian scientific context.

It is pointed out that in the stock market the search for information is presented under distinct ways, considering that this environment is formed by a diversity of investors, each one with a distinct goal. Another important point arises from the fact that this environment also has as strong characteristic, the oscillations arising from the supply and demand inherent to the market dynamic itself, as well as cyclical events which may reflect in the performance of stock market in general. Thus, the information search behavior in this context may vary due to several factors.

In this perspective, it is pointed out that the search for value-added information, including the conjectural, micro and macro-economic, comparative and historic analysis as well as business and companies' scenario analysis, aims to approach the investor to the reality and to the market behavior, in a way that he can make the best decision, or at least the right decision (LOPES; VALENTIM) [11].

When the investors obtain new information which projects the impact about the expected future of a company, such as cash flows, investments, financial results, among others, this capitalization of accurate information is set into the main foundation to the decision making (MORK) [12].

In order to the decision making process of investors being effective, it is fundamental that they obtain direct, clear, relevant, and mainly reliable information. However, the efficiency regarding the information appropriation to the construction of knowledge in this context depends fundamentally of the search behavior of this information.

\section{Proposal of Model of Information Search to the Stock Market Context}

The information search behavior developed by the investors during the process of knowledge construction is necessary for them to perform in this market in a safer way. When events which might jeopardize their assets occur, such as worldwide crisis for example, the investors start to search information in a specific way, which means that information search behavior in this context may be modified according to the market's dynamic. Thus, it may be understood that the investor knowledge is modified during the information analysis process, as well as the information is appropriate according to the search behavior of the informational individual, and as a result of this appropriation the investor changes his mental representations, changing then the investment practice. 
Although the information overlapped to the daily tasks is considered important, when you look at the social and cultural factors which influence the individuals' behavior, as well as the perceptions of determined groups or the supports used and the specific characteristics of the search behavior, in the context of the stock market it is important to use a model which allows the comprehension regarding the investors behavior under a broader perspective. In this sense, the model of Wilson was chosen, because it is one of the most cited in the research about informational behavior and, for considering the investigation of several areas in its scope, including Psychology, the consumer behavior, the organizational decision making and information systems.

Even though the model of Wilson contemplates all the process of the informational behavior, it is possible to extract to this research only the aspects related to the information search behavior of investors in the stock market.

In this sense, the model of information behavior of Wilson [1] (Figure 4) defines an interactive process in 6 steps, starting with the recognition by the individual for the need of information, which is a prerequisite to start out any activity of information search. In the following stages, Wilson introduces the concept of mechanism activation, and that is because although the individual recognizes their information need, the stress factor to obtain such information should be high enough to urge him to the action, however this stress cannot be as high as to cripple the process and, thus postpone the beginning of the search. This factor of activation is supported by the coping theory.

Among the determination of an information need and the beginning of an action to satisfy this need, Wilson proposes an activation mechanism, using the Risk/Reward Theory and the Learning Social Theory, as well as the concept of self-efficacy with explanatory foundations. The Risk/Reward Theory subsidizes the principles related to the information obtaining and that motivates a person perform or give up the to the search behavior, while the Social Learning Theory and the concept of selfefficacy subsidize the individual in the actions in the information search, in order to provide the necessary motivation to perform the search demanding activities. Besides activating the mechanism to the information search, each individual is challenged by a set of factors which act in way to stimulate or difficult the access to information. Wilson names this set of intervenient variables, which he classifies as environment or the ones external to the individual; social, which are introduced externally when they are internalized by the individual; personal (psychological or demographic), which cannot be separated from the individual; and the variables which refer to the role that an individual has in a certain reality, including also interpersonal variables.

After activating the mechanisms and the intervenient variables the filters to the implementation of an information search process may have beginning, for that four degrees which include passive attention (information acquisition without deliberate search, such as watching television programs) are identified: the passive search (an individual acquires information which may be relevant while performing another kind of research), active search (active search of information), as well as the continuous search, which may occasionally update or expand the degree of knowledge already established (ideas, beliefs and values). Finally, the information obtained are processed by the individual, but not necessarily used.

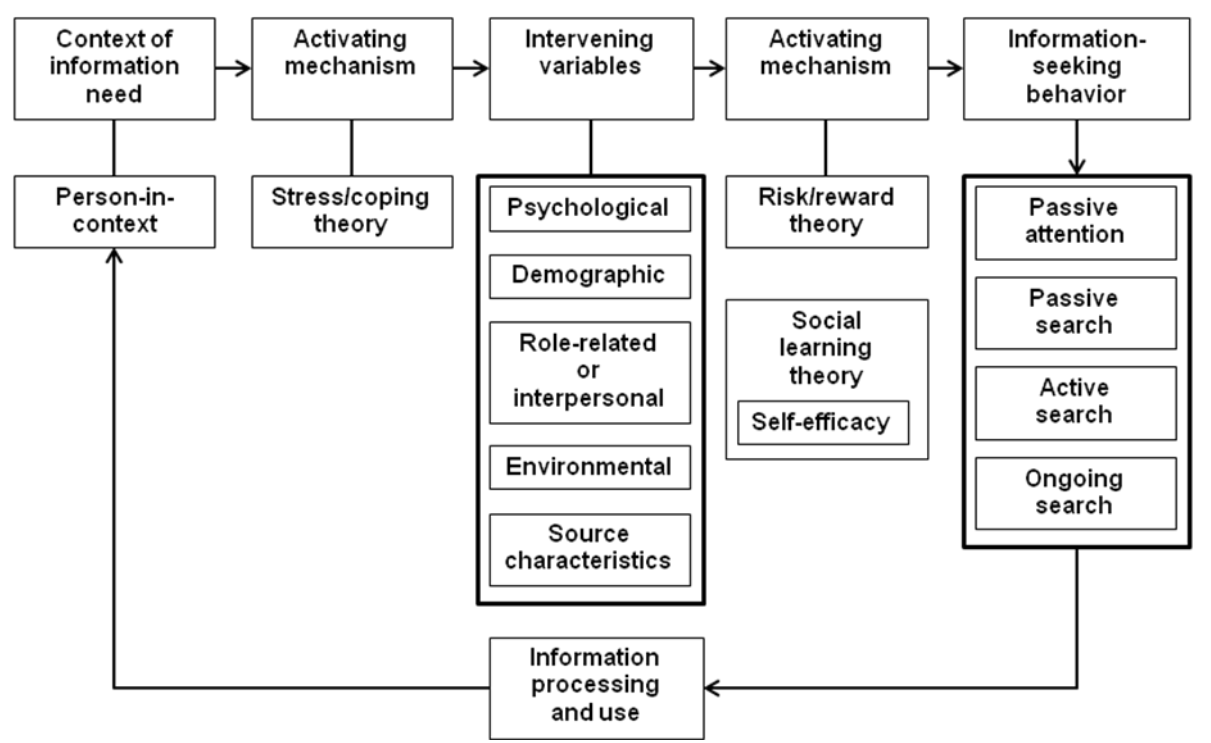

Source: Wilson [1].

Figure 4. Wilson-Informational behavior model. 
The model of Wilson is used in the extent of this research proposal regarding that it focuses the individual, considering his specific needs of information, as well as the active search of the necessary information on their own. This is very relevant in the context of the stock market area, since a meaningful proportion of investors make their own decisions of investment. Still considering that the stock market coexists daily with a high amount of relevant information, this model considers properly the risk which incurs during the information search process, considering the risk and the potential reward.

Finally, the model of Wilson provides a comprehensive framework to the identification of potential barriers of the information acquisition that an individual faces when looking for relevant information to the investment decision making (for example, barriers regarding to the knowledge or accessibility to the information sources), its effects on the information obtained through the search behavior (such as the choice of information sources of support to the several research models), as well as the mechanisms of information processing and use (for example, when the processed information is effectively).

\section{Research Structure and Results}

Considering this as being a proposal which has the objective to stimulate future studies, pointing out that in Brazil there is not a conceptual and empiric basis which considers the information search behavior in the context observed so far, it was opted by the exploitation of Wilson's model [1] as basis for the evaluation of the information search behavior by investors of the stock market area. In this sense, a study has been carried out with basis in the report of an investor, regarding the need of accomplishment of a pre-test which may serve as guide for further analysis. Due to the methodology adopted, the report of only one investor was used as basis for investigation, turning it impossible to extrapolate such result to a greater universe.

The report was transcribed according to the parameters established in the model of Wilson [1], being conducted through structured questions based on these parameters, and the variables were added or left out according to the occurrences reported. The investor participant in the research is a client of a brokerage and has performed in the stock market for eight years. For this research, the report chose an event occurred in the stock market segment in 2008, characterized by a worldwide economic crisis, arising from factors involving the American Real Estate. This crisis for focusing on the main worldwide economy came to reach emerging markets, such as Brazil, culminating in the fall of companies' stock values in a general way. Face to this event, many investors realized a scenario of great devaluation of assets which were part of their investment, what generated, in some individuals, doubts about the behavior to be adopted given such scenario of high risk. Under this perspective, the search for consistent information is fundamental. The results obtained were organized and are presented in Figure 5.

The information search behavior and its different ways of research influence the information processing and further construction of knowledge about determined topic of interest. On this context, the model of Wilson configures itself as an instrument possibly applicable, mainly for presenting subsidies to make it possible to identify the stages an individual goes through during this process and, finally, whether the information found satisfy the user or not.

It is important to point out that in this specific case it may be observed that the cognitive competences of the individuals are fundamental to cover these elements, considering the activation mechanisms and intervenient variables, which may impact on the ability to assimilate the information and use it. This condition should be considered, mainly within the scope of the stock market since the participants in this environment, in spite of having similar goals, have cultural, social and financial diversity. Another fundamental aspect regards the need to observe the context of the information need, which may vary a lot in this environment, since an individual may be led to search daily market information in typical situations, but may present another activation need behavior in atypical situations, as the case of the investor analyzed on this research.

Besides, it is pointed out that each intervenient variable may cause a favorable impact or make the process of information search difficult, therefore, the understanding of these variables would provide greater comprehension of client approach in the search of advisement in the extent of the stock market segment. In this case it has been observed that the cycle ended with the obtaining of information, featuring a cognitive process of informational change leading to the construction of knowledge necessary to the decision making.

\section{Conclusions}

The research reported may be understood as a pre-test, and be considered as the beginning of the development of a more extensive study about the information search behavior by investors in the stock market segment. The analysis of the intervenient variables may increase the comprehension of the reasons which lead the investors to prefer other sources of information about the stock market to the ones existing in the traditional media or in the brokerage firms, showing a trend to an active informational and self-sufficient search behavior, which may in many cases lead to mistakes. The intervenient variables 


\begin{tabular}{|c|c|}
\hline $\begin{array}{c}\text { Context of } \\
\text { information need }\end{array}$ & $\begin{array}{l}\text { Market shows oscillations, and in some days falls over } 5 \% \text { were observed. } \\
\text { - Investor with investments over R } \$ 500.00000 \text { in shares of several companies. } \\
\text { his investments. }\end{array}$ \\
\hline $\begin{array}{l}\text { Activation } \\
\text { mechanism }\end{array}$ & $\begin{array}{l}\text { - The mechanism activator of the need in this context was resulting from the cognitive process, being related to the need to } \\
\text { know the reason why the market shows a considerable decrease, or, the need to answer to a questioning, a shortage of infor- } \\
\text { mation or doubt. In this case, the individual presented strong reason to trigger the process of informational search. }\end{array}$ \\
\hline $\begin{array}{r}\text { Interve } \\
\text { varial }\end{array}$ & $\begin{array}{l}\text { Regarding the psychological source, the need of informational search arising from the possibility of great loss was observed, } \\
\text { which in turn would be consequence of a decision not-well founded (the possibility of loss in general causes fear, including } \\
\text { emotional shocks). } \\
\text { About the demographic variable, it is presented as leading factor, as it was about a 38-year-old investor. In this context, in } \\
\text { general, it has been observed that investors aged } 30 \text { and } 50 \text { show less fear regarding the risks presented by the investments } \\
\text { however they are eager for information. } \\
\text { The environment intervenient was marked by the lack of active participation of the investments advisory which presented } \\
\text { delay in the information reporting, such as a little clarity in the reports issued, as well as the lack of time of the individual to } \\
\text { dedicate himself to deeper searches. } \\
\text { The characteristics of the sources also intervened in a considerable way, however the web sites with news related to the mar- } \\
\text { ket are varied and the environment exclusive for investors of the advisory company did not present data in a timely manner, } \\
\text { besides the report of the difficulties presented in the use of the resources available in this environment. }\end{array}$ \\
\hline $\begin{array}{c}\text { Activation } \\
\text { of mechanisms }\end{array}$ & $\begin{array}{l}\text { - According to the Risk/Reward Theory, it has been observed that the individual had taken the risk of not finding consistent and } \\
\text { timely information. However, the evaluation regarding the time, considering that this is a volatile environment and with great } \\
\text { speed of oscillations, opted by the search through existing possibilities, seeking as return the protection of their investments. } \\
\text { - Regarding the Social Learning Theory and the concept of self-efficacy, these appear when considered that the individual has } \\
\text { shown a behavior resulting from the consciousness of his autonomy in the solution of that informational problem, having, } \\
\text { then, to fall back on his own intuition coupled with the previous knowledge about the information sources. }\end{array}$ \\
\hline $\begin{array}{c}\text { Information } \\
\text { search Behavior }\end{array}$ & $\begin{array}{l}\text { - Considering the urgent need of information source, it has been observed that the search behavior followed the criterion of } \\
\text { "active search", mainly through interpersonal channels—-what means, the channels on which the information source is one } \\
\text { person—on this case being reported through the search by an analyst of the area. However, the channels that are considered } \\
\text { "passive", but that are most commonly used - newspapers, internet resources—-were used, but they did not present informa- } \\
\text { tion in a timely and fast way. }\end{array}$ \\
\hline $\begin{array}{l}\text { Process } \\
\text { use of inf }\end{array}$ & $\begin{array}{l}\text { - After the conclusion of all the stages, and not having shown movement of withdrawal it was possible to observe that the in- } \\
\text { vestor was able to get relevant information to their investment decision-making, having reported the achievement of opera- } \\
\text { tions which reduced his losses. }\end{array}$ \\
\hline
\end{tabular}

Source: Research Data.

Figure 5. Information search behavior.

examined on this case show that there is a potential of improvement to the processes of dissemination of information as subsidy to the construction of knowledge for investors.

In this perspective, it is recommended also to consider the several characteristics from the point of view of the cognitive diversity, from the intervenient variables which may change effectively the informational search behavior, as well as the condition observed in the extent of the stock market, considering that factors such as final crisis alter significantly the behavior.

In this sense, the objective of this research was to investigate the informational needs, the context and the intervenient variables which interfere or not in the information search behavior of investors, in an attempt to get a deeper comprehension about the subject, as well as to propose the continuity of studies based on this study proposal.

\section{REFERENCES}

[1] T. D. Wilson, "Information Behavior: An Interdisciplinary Perspective,” Information Processing and Manage- ment, Vol. 33, No. 4, 1997, pp. 551-572.

http://ptarpp2.uitm.edu.my/silibus/infoBehavior.pdf http://dx.doi.org/10.1016/S0306-4573(97)00028-9

[2] M. E. Nassif, L. S. Venâncio and L. C. H. Junqueira, "Sujeito, Contexto e Tarefa na Busca de Informação: Uma Análise sob a Ótica da Cognição Situada,” DataGrama Zero: Revista de Ciência da Informação, Vol. 8, No. 5, 2007. http://www.dgz.org.br/out07/Art_04.htm

[3] T. D. Wilson, "Information Needs and Uses: Fifty Years of Progress,” In: B. C. Vickery, Fifty Years of Information Progress: A Journal of Documentation Review, Aslib, London, 1994, pp. 15-51.

[4] C. C. Kuhlthau, "Inside the Search Process: Information Seeking from the User's Perspective," Journal of the American Society for Information Science, Vol. 42, No. 5, 1991, pp. 361-371. http://dx.doi.org/10.1002/(SICI)1097-4571(199106)42:5< 361::AID-ASI6>3.0.CO;2-\#

[5] T. D. Wilson, "Models in Information Behavior Research," Journal of Documentation, Vol. 55, No. 3, 1999, pp. 249270. http://ptarpp2.uitm.edu.my/silibus/model.pdf http://dx.doi.org/10.1108/EUM0000000007145

[6] C. C. Kuhlthau, "A Principle of Uncertainty for Information Seeking,” Journal of Documentation, Vol. 49, No. 4, 1993, pp. 339-355. http://dx.doi.org/10.1108/eb026918 
[7] T. D. Wilson, "Human Information Behavior," Information Science Research, Vol. 3, No. 2, 2000, pp. 49-55. http://inform.nu/Articles/Vol3/v3n2p49-56.pdf

[8] A. F. Andrezo and I. S. Lima, "Mercado Financeiro: Aspectos Históricos e Conceituais,” 2nd Edition, Pioneira Thomson Learning, São Paulo, 2002.

[9] J. L. Pinheiro, "Mercado de Capitais: Fundamentos e téCnicas,” 4th Edition, Atlas, São Paulo, 2007, 354 p.

[10] A. A. Barreto, “A Questão da Informação,” São Paulo em Perspectiva, Vol. 8, No. 4, 1994. http://dx.doi.org/10.1590/S0102-88392002000300010
[11] E. C. Lopes and M. L. P. Valentim, "Mediação da Informação no Âmbito do Mercado de Capitais,” Informação \& Informação, Vol. 13, 2008, pp. 87-106.

http://www.uel.br/revistas/uel/index.php/informacao/artic $\underline{\text { le/view/1844/1557 }}$

[12] R. Morck, B. Yeung and W. Yu, “The Information Content of Stock Markets: Why Do Emerging Markets Have Synchronous Stock Price Movements?” Journal of Financial Economics, Vol. 58, 2000, pp. 215-238. http://time.dufe.edu.cn/spti/article/harvard/1879.pdf http://dx.doi.org/10.1016/S0304-405X(00)00071-4 